\title{
$\mathrm{NFC}$ 알고리즘을 이용한 태양광 발전의 새로운 MPPT 제어
}

\section{A Novel MPPT Control of Photovoltaic Generation Using NFC Algorithm}

\author{
장 미 금**최 정 식**정 동 화 ${ }^{\dagger}$ \\ (Mi-Geum Jang $\cdot$ Jung-Sik Choi $\cdot$ Dong-Hwa Chung)
}

\begin{abstract}
This paper proposes a novel maximum power point tracking(MPPT) using a new fuzzy control(NFC) algorithm for robust in insolation variation. Maximum power point(MPP) of solar cell has to achieve for improving output efficiency because it is changed with insolation and temperature. Conventional MPPT controller such as constant voltage $(\mathrm{CV})$, perturbation and observation(PO) and incremental conductance(IC) are researched. But these controller have the problem that is failure to MPP with environment changing.

The proposed NFC controller is based the fuzzy control algorithm and able to robust control with environment changing. Also the proposed controller of PV system is modeled by PSIM and the response characteristics according to the parameter variation is compared and analyzed. The validity of this controller is proved through response results.
\end{abstract}

Key Words : PV system, MPPT control, NFC, Insolation, Temperature, Efficiency

\section{1. 서 론}

현재 세계에서 사용되고 있는 에너지를 에너지원별로 분 류하여 보면 석유 $32[\%]$, 석탄 26[\%], 천연가스 20[\%]로서 이들 화석연료만으로도 전체의 $80[\%]$ 가까이 차지하고 있 다. 또한 인류가 가장 많이 사용하고 있는 전기에너지는 대 부분이 화력발전이나 원자력발전에 의존하고 있는 실정이 다. 화력발전의 경우 화석연료 자원의 한정성, 에너지 대량 소비에 따른 산성비, 지구 온난화, 오존층의 위협 등의 환경 파괴 문제가 크게 대두되고 있다. 원자력 발전의 경우에는 연료인 우라늄 $1[\mathrm{~g}]$ 에서 석탄 $3[\mathrm{ton}]$ 에 해당하는 열에너지가 얻어지나, 핵분열에 의해서 생기는 방사능의 원자로 주변에 누출, 방사성 폐기물의 처분 및 재처리, 발전소 입지 문제 등의 안전도 문제가 제기되고 있다.[1]

이에 대한 대책으로 선진국에서는 대체 에너지 개발을 추 진하고 있으며, 그 중에서도 신 에너지원으로써 공해가 없으 며 무한한 태양에너지를 이용하는 태양광 발전시스템이 새 로이 각광을 받고 있다.[2][3]

태양에너지를 전기에너지로 변환하기 위한 태양광 발전시 스템 구성을 크게 나누어보면 태양전지 어레이와 태양전지 의 최대 전력점 제어를 위한 $\mathrm{DC}-\mathrm{DC}$ 컨버터 및 직류전력을 교류전력으로 변환해주는 인버터로 구성된다.[4][5] DC-DC 컨버터를 통해 태양전지가 최대 전력점에서 운전되기 위한 MPPT(Maximum Power Point Tracking) 제어는 다양하게

\footnotetext{
* 정 회 원 : 전자부품연구원

† 교신저자, 펠로우회원 : 순천대 공대 전기공학과 정교수·공박

E-mail : hwa777@scnu.ac.kr

접수일자 : 2011년 3월 15일

최종완료 : 2011년 8월 26일
}

연구되어 왔다.

태양전지의 최대 전력점은 일사량과 온도에 따라 변하기 때문에 출력 효율을 증가시키기 위해 최대 전력점에서 동작 하도록 최대 전력점을 추적하는 제어는 매우 어렵다. 이를 위해 최대 전력점 추적제어 기술, 고효율 에너지 변환 인버 터 기술은 지속적인 연구가 진행되고 있다. 최대 전력점 추 적을 위한 일반적인 요구 사항은 시스템이 간단하고 가격이 저렴하며 PV 모듈에 비추는 태양광 일사량의 불평형에 대 하여 최대출력을 얻는 방법이 제안되고 있다.[6][7] 태양전지 의 특성은 변하지 않지만 최대출력 동작점이 변하기 때문에 최대출력을 얻도록 동작시키는 $\mathrm{MPPT}$ 제어방식은 정전압 제어방식과 비선형함수 계산방식[8], $\mathrm{PO}$ (Perturbation and Observation) 제어방법[9], IC(Incremental Conductance) 제 어방법[10] 등이 대표적이다. 그러나 일사량이 급변하는 경 우에 $\mathrm{MPP}$ 를 추적하지 못하고, 계산량이 많아 고성능 $\mathrm{CPU}$ 가 요구되며 추적효율이 낮다는 단점이 있다.[11-14]

이러한 문제점을 해결하기 위해 본 논문에서는 $\mathrm{NFC}(\mathrm{New}$ Fuzzy Conrol)를 이용한 새로운 MPPT 제어 알고리즘을 제 시한다. $\mathrm{NFC}$ 제어 알고리즘은 일사량과 온도 등의 환경변화 에 대해 강인성을 유지할 수 있으며, 정상상태에서의 자려진 동이 거의 없기 때문에 효율을 높일 수 있다. 본 논문에서는 제시한 $\mathrm{NFC}$ 알고리즘과 종래의 $\mathrm{CV}, \mathrm{PO}$ 및 $\mathrm{IC}$ 제어 알고리 즘의 응답특성을 비교하였다. 일사량이 일정한 경우와 일사 량이 변동할 경우에 대한 응답특성을 비교, 분석하여 본 논 문에서 제시한 알고리즘의 타당성을 입증하였다.

\section{2. 태양전지 모델링}

빛이 조사될 때 광기전력 효과를 이용한 태양전지의 등가 
회로를 그림 1 과 같이 나타내며, 태양전지의 출력전류에 대 한 식은 다음의 등가회로를 기반으로 식 (1)과 같이 나타낼 수 있다.

여기서, $I_{p h}$ 는 광전류, $I_{d}$ 는 다이오드 포화전류이다.

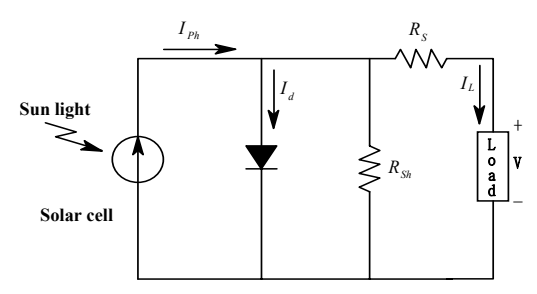

그림 1 태양전지의 등가회로

Fig. 1 Equivalent circuit of solar cell

$$
\begin{aligned}
& I=I_{s c}-I_{d}-I_{s h} \\
& I=I_{p h}-I_{d}-\frac{\left(V_{p v}+R_{s} I\right)}{R_{s h}}
\end{aligned}
$$

태양전지의 전류-전압 특성곡선을 얻기 위한 수식은 다 음과 같이 표현된다.

$$
\begin{aligned}
& I_{p h}=I_{s c} S_{N}+I_{t}\left(T_{c}-T_{r}\right) \\
& I_{d}=I_{o}\left[\exp \left(\frac{q\left(V_{L}+I_{L} R_{s}\right)}{A k T}\right)-1\right] \\
& I_{o}=I_{o r}\left[\frac{T_{c}}{T_{r}}\right]^{3} \cdot \exp \left(\frac{q E_{g}}{B k}\left(\frac{1}{T_{r}}-\frac{1}{T_{c}}\right)\right) \\
& I_{L}=I_{p h}-I_{d}-\frac{V_{L}+I_{L} R_{s}}{R_{s h}}
\end{aligned}
$$

여기서, $S_{N}$ : 단위 일사량

$I_{t}$ : 표면온도 $1^{\circ} \mathrm{C}$ 상승 시 단락 전류 온도계수 $[\mathrm{A} / \mathrm{K}]$

$T_{c}$ : 태양전지 온도[K], $T_{r}$ : 태양전지 동작 기준온도[K]

$B$ : 제조상수

$I_{o r}$ : 태양전지 동작 기준온도에서 역포화전류[A]

$E_{g}:$ 에너지 밴드 갭

(Si PN 접합 에너지 Gap, 1.12[eV]),

또한, 개방전압 $V_{o c}$, 단락전류 $I_{s c}$, 및 $\mathrm{FF}$ (Fill Factor) 등 3 개의 변수는 에너지 변환 효율과 관련되는 파라미터이며, 태양전지의 등가회로부터 단락전류 $I_{s c}$ 는 이상적으로 광전 류 $I_{P h}$ 와 일치하고, 다이오드 포화전류 $I_{d}$ 에 의해서 결정되 는 태양전지의 개방전압은 다음 식과 같다.

$$
V_{o c}=\frac{k T}{q} \ln \left[\frac{I_{P h}}{I_{d}}+1\right]
$$

여기서, $V_{o c}$ 는 개방전압, $k$ 는 볼츠만 상수, $q$ 는 전하[C],
$T$ 는 태양전지 동작온도 $[K]$ 를 나타낸다. 또한, 온도변화에 따른 단락전류와 개방전압의 관계식은 다음과 같다.

$$
I_{s c}=I_{o}\left[\exp \left(\frac{q V_{o c}}{k T}\right)\right]
$$

태양전지에 연결된 부하 저항의 크기를 조절함으로써 임 의의 최적 동작점에서 최대 출력 $P_{m p}$ 가 얻어지게 되며, 다 음 식과 같다.

$$
P_{m p}=V_{m p} \cdot I_{m p}
$$

부하저항에서 소비되는 에너지 $P_{\text {out }}$ 는 다음 식과 같다.

$$
P_{\text {out }}=V \cdot I=V \cdot\left[I_{p h}-I_{0}\left[\exp \left(\frac{q V}{n k T}-1\right)\right]\right]
$$

최적 부하조건에서 $\frac{d P_{\text {out }}}{d V}=0$ 이므로, 최적 동작전압 $V_{m p}$, 최적 동작전류 $I_{m p}$ 는 다음 식과 같다.

$$
\begin{aligned}
& V_{m p}=\exp \left(\frac{q V_{m p}}{n k T}\right)\left(1+\frac{q V_{m p}}{n k T}\right)=\frac{I_{s c}}{I_{0}}+1 \\
& I_{m p}=\frac{\left(I_{s c}+I_{0}\right) \cdot\left(\frac{q V_{m p}}{n k T}\right)}{1+\left(\frac{q V_{m p}}{n k T}\right)}
\end{aligned}
$$

여기서 $P_{m p}$ 가 커지기 위해서는 특성곡선에서 $I_{m p}$ 와 $V_{m p}$ 가 $I_{s c}$ 와 $V_{o c}$ 에 가까워야 한다. 여기서 $\mathrm{FF}$ 는 다음과 같다.

$$
F F=\frac{P_{m p}}{V_{o c} I_{s c}}=\frac{V_{m p} I_{m p}}{V_{o c} I_{s c}}
$$

변환효율은 태양전지에서 얻을 수 있는 최대의 전기 에너 지를 입사광 에너지로 나눈 값으로 다음 식과 같다.

$$
\eta_{P V}=\frac{V_{m p} \cdot I_{m p}}{P_{i n}}=\frac{F F \cdot V_{o c} I_{s c}}{P_{i n}}
$$

식 (2) (6)을 이용하면 태양전지 어레이의 출력특성을 얻을 수 있으며 그림 2와 그림 3은 PSIM으로 구현한 태양 전지 어레이의 모의실험 결과 파형으로 일사량과 온도 변화 에 대한 전류-전압 특성곡선을 보여주고 있다.

그림 2는 일사량에 따른 태양전지 출력의 변화를 보여주 고 있으며 일사량의 변화 시 태양전지의 개방전압은 큰 변 화가 없는 반면 출력전류가 크게 변화하고 있음을 알 수 있 다. 그림 3 은 온도 변화에 따른 태양전지의 출력특성을 나 
타낸다. 일사량이 변화한 경우에 비해 온도가 변화한 경우 에는 전류의 변화보다 전압 변화가 큰 것을 알 수 있다.

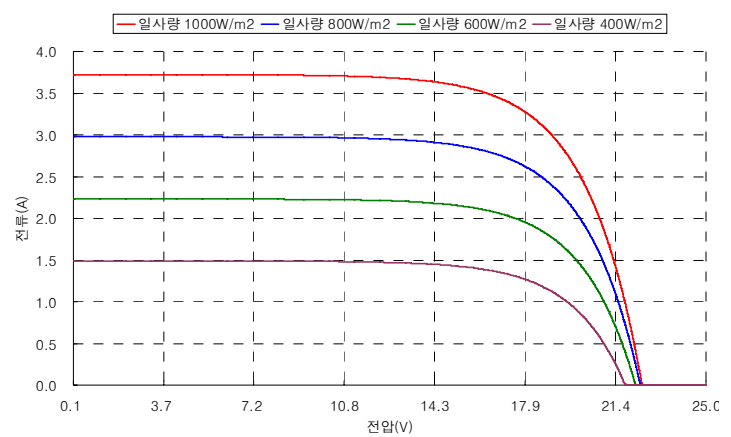

그림 2 일사량 변화에 대한 I-V 특성곡선

Fig. $2 \mathrm{I}-\mathrm{V}$ characteristic curve with radiation changing

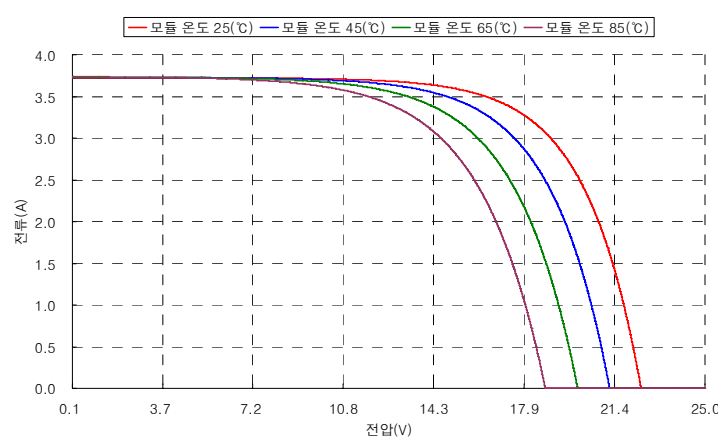

그림 3 온도 변화에 따른 $\mid-V$ 특성곡선

Fig. $3 \mathrm{I}-\mathrm{V}$ characteristic curve with temperature changing

\section{3. 종래의 MPPT 제어}

\section{$3.1 \mathrm{CV}$ 방법}

태양전지의 최대 출력전압이 일사량이나 태양전지 표면온 도에 크게 영향을 받지 않는다는 점에 착안한 방법이다. $V_{r e f}=0.76 V_{o c}$ 로 설정하여 전압 지령치를 바꾸지 않고 사전에 계절별 또는 월별 평균 태양전지 표면온도와 평균 일사량을 기본으로 실험을 통하여 최적의 태양전지 동작점을 산출한 후 정전압으로 제어하는 기법이다. 따라서 이 기법은 출력 에 대해 전력량이 필요하지 않는다. Boost 컨버터의 duty cycle은 제어 회로에 의해 결정되고, 출력 측 $\mathrm{DC}$ 전압은 정 상상태 조건의 $V_{r e f}$ 값에 의해 일정한 값으로 유지된다. 이러 한 $\mathrm{CV}$ 제어방법은 어레이 및 $\mathrm{DC}$ 측의 전류 센서를 줄일 수 있는 장점이 있지만 일사량 급변 시 정확한 $\mathrm{MPP}$ 를 추종하 지 못해 출력효율이 감소되고 태양전지 모델링의 정확성에 성능이 좌우되는 단점이 있지만, 어레이 및 $\mathrm{DC}$ 측의 센서를 줄일 수 있는 장점을 갖는다. 그림 4 는 $\mathrm{CV} \mathrm{MPPT} \mathrm{방법의}$ 제어 알고리즘을 나타내고 있다.

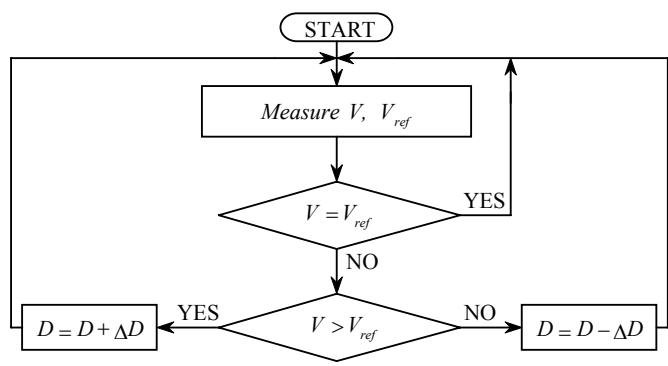

그림 $4 \mathrm{CV} \mathrm{MPPT}$ 방법의 제어 알고리즘

Fig. 4 Control algorithm of CV MPPT method

\subsection{IC 방법}

IC 제어방법은 부하 임피던스와 태양전지 어레이 출력의 컨덕턴스와 증분컨덕턴스를 비교하여 최대 전력점을 추종하 는 방법이다. 이는 태양전지의 $P-V$ 특성곡선을 이용하여 $\mathrm{PO}$ 방법에서 간과하고 있는 전압 변동 폭이 ' 0 ' 인 경우의 제어 알고리즘을 추가하여 그 특성이 안정적이다.

그림 5는 IC 제어방법의 원리를 나타내며, 태양전지의 $P-V$ 출력곡선의 기울기는 $d P_{P V} / d V_{P V}$ 로 나타낼 수 있다. 그림 5 에서 최대 전력점은 $\mathrm{MPP}$ 점에 위치하고 있으며, 이 때 의 기울기는 0 이다. 최대 전력점을 기준으로 왼쪽은 양의 기울기를 가지고, 오른쪽은 음의 기울기를 가지고 있음을 알 수 있다.

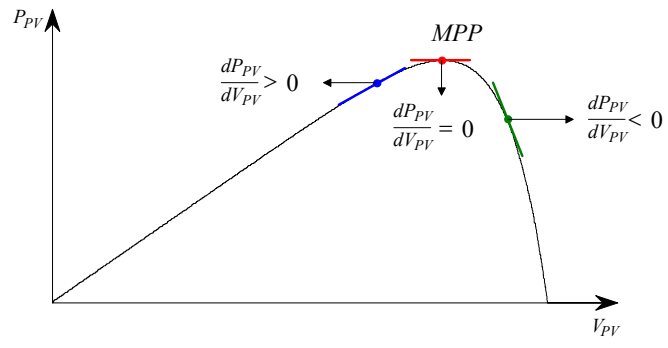

그림 5 IC MPPT 방법의 제어 원리

Fig. 5 Control theory of IC MPPT

$\mathrm{IC}$ 제어방법의 전압-전류 식은 다음과 같다.

$$
\begin{aligned}
& \frac{d P_{P V}}{d V_{P V}}=\frac{d\left(V_{P V} I_{P V}\right)}{d V_{P V}}=I_{P V}+V_{P V} \frac{d I_{P V}}{d V_{P V}} \\
& \frac{1}{V_{P V}} \frac{d P_{P V}}{d V_{P V}}=\frac{I_{P V}}{V_{P V}}+\frac{d I_{P V}}{d V_{P V}} \\
& \text { 여기서 } G=\frac{I_{P V}}{V_{P V}}, \Delta G=\frac{d I_{P V}}{d V_{P V}} \text { 이다. }
\end{aligned}
$$

식 (16)을 이용한 IC MPPT 방법의 제어 알고리즘은 그 림 6 과 같다. 


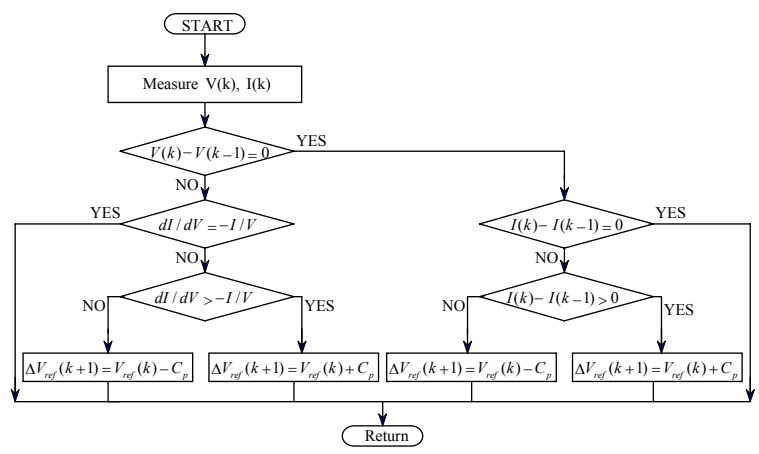

그림 6 IC MPPT 방법의 제어 알고리즘

Fig. 6 Control algorithm of IC MPPT method

IC 제어방법은 빠른 환경변화에서 MPPT 성능이 매우 좋 은 장점이 있으나, 많은 계산량으로 인해 고성능 $\mathrm{CPU}$ 가 필 요하므로 결국 시스템 단가를 상승시키는 단점이 있다.

\subsection{PO 방법}

종래의 $\mathrm{PO}$ 제어방법은 간단한 피드백 구조를 갖으며 소 수의 측정파라미터를 갖기 때문에 널리 사용된다. 이는 태 양전지의 전압을 주기적으로 증가 또는 감소시킴으로써 동 작하며, 이전의 교란주기 동안의 태양전지 어레이 출력전력 과 함께 현재 어레이 출력전력 비교에 의해 최대전력의 상 태를 연속적으로 추적하며 찾는다. 이는 태양전지의 동작점 을 규정하는 태양전지 출력단 전압 $\left(V_{P V}\right)$ 제어 시에 전압을 일정한 폭으로 변동시킨 후 태양전지 출력전력 $\left(P_{P V}[n]\right)$ 을 관 측하고, 이를 이전 출력전력 $\left(P_{P V}[n-1]\right)$ 과 비교하여 출력이 증가하는 방향으로 전압 $\left(V_{P V}^{*}\right)$ 을 상승 또는 하강시킴으로써 최대 전력점을 추종하는 방식이다.

$\Delta V_{r e f}$ 와 $\Delta P(k)$ 의 극성에 따라 스텝 값을 조절하여 다음 기준전압을 결정하는 방법이 $\mathrm{PO}$ 방식이며, 제어 알고리즘은 다음과 같다.

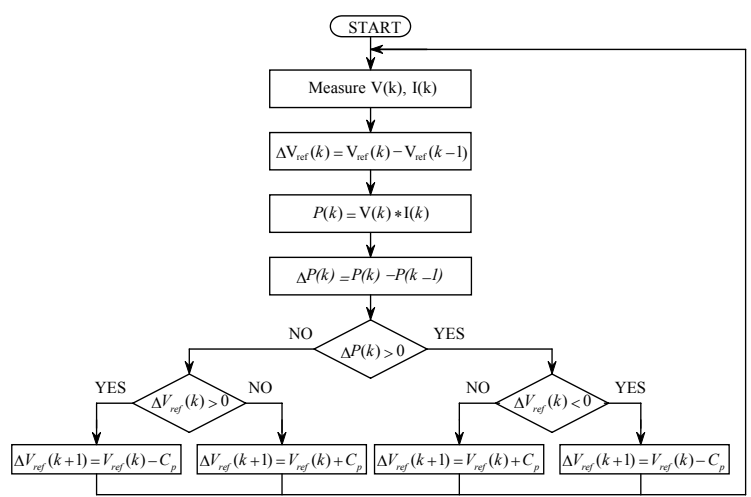

그림 $7 \mathrm{PO} \mathrm{MPPT}$ 방법의 제어 알고리즘

Fig. 7 Control Algorithm of PO MPPT method

그러나 이 방법은 $\mathrm{MPP}$ 에 이르렀을 때 일정 혹은 천천히 변하는 환경조건에서 자려진동하며 그 결과 태양전지 어레
이의 손실이 발생하게 된다. 또한 환경조건이 급변하는 경 우 $\mathrm{MPP}$ 속도가 늦어지게 되므로 스텝 값의 결정이 중요하 게 되며 급변하는 일사량에는 적용하기 힘들다는 단점을 가 지고 있다.

\section{4. 제시한 NFC 방법}

퍼지제어는 인간의 판단 등, 애매성을 포함한 제어 알고 리즘을 if-then 형식으로 표현하고, 퍼지 추론을 이용하여 컴퓨터로 실행시키는 것이다. 퍼지제어기의 구조는 그 내부 에 취급되는 정보가 퍼지집합의 형태이므로 재래식 제어기 와는 매우 다를 것으로 예상되지만, 퍼지제어기도 하나의 제 어기로서의 기본 형태는 일반 제어기와는 유사하며 단지 제 어기 안에서 유통되는 정보량의 형태가 다를 뿐이다. 그림 8은 퍼지제어 시스템의 기본 구조를 나타낸다.

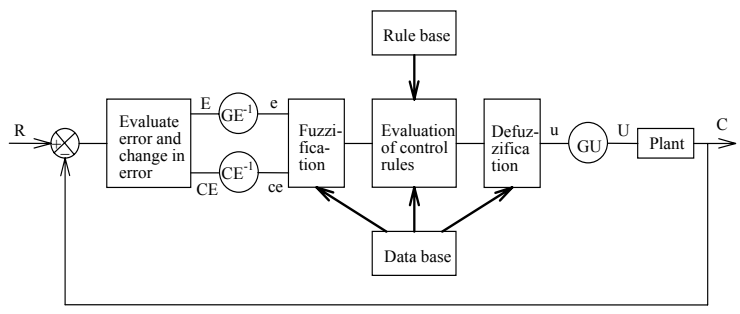

그림 8 퍼지제어 시스템의 기본적인 구조

Fig. 8 Base structure of a fuzzy controlled system

$\mathrm{NFC}$ 는 2 개의 입력변수를 갖으며 샘플링 구간 $k$ 에서의 입력변수 $E(k)$ 와 $C E(k)$ 는 다음과 같이 정의된다.

$$
\begin{aligned}
& E(k)=\frac{V_{p v}(k) \cdot I_{p v}(k)-V_{p v}(k-1) \cdot I_{p v}(k-1)}{V_{p v}(k)-V_{p v}(k-1)} \\
& C E(k)=E(k)-E(k-1)
\end{aligned}
$$

퍼지언어 변수는 7단계, 즉 $\mathrm{PB}$ (Positive Big), $\mathrm{PM(Positive}$ Middle), PS(Positive Small), ZO(Zero), NS(Negative Small), NM(Negative Middle), NB(Negative Big)로 정하였 으며, 그림 9 는 입 - 출력에 대한 7 개의 기본 언어변수에 따 른 삼각형 모양의 소속함수를 나타낸다.
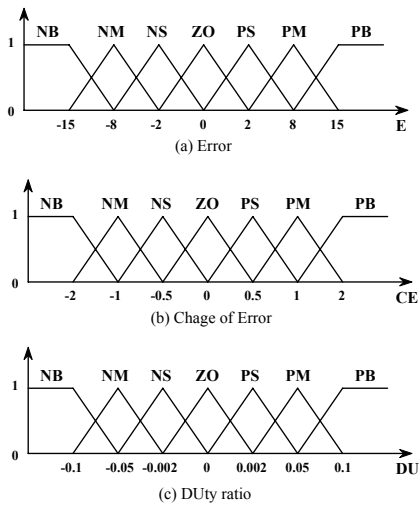

그림 9 오차와 오차변화분 및 시비율에 대한 멤버쉽 함수 Fig. 9 The membership function for the E, CE and DU 
표 1 은 퍼지제어기의 제어규칙을 나타내는데, 여기서는 행렬의 각각의 요소들은 E(error), CE(change of error) 와 컨 버터의 시비율 변화량 $d D$ 를 나타낸다.

표 1 에서 제어규칙의 한 가지 예를 들면 아래와 같다.

"IF E is PB AND CE is ZO THEN DU is PB."

즉, 전압에 대한 전력의 특성곡선에서 기울기가 매우 크 고 그 기울기에 대한 변화량이 없으면 제어 출력값을 매우 크게 증가시키라는 의미이며 또한 입력신호인 오차 $E$ 를 'Zero'로 취하는 의미는 시비율이 ' 0 '이 되도록 제어규칙을 설계한다.

표 1 NFC 규칙 베이스

Table 1 NFC Rule Base

\begin{tabular}{|c|c|c|c|c|c|c|c|}
\hline E CE & NB & NM & NS & ZO & PS & PM & PB \\
\hline NB & NB & NB & NB & NB & NM & NS & ZO \\
\hline NM & NB & NB & NM & NM & NS & ZO & PS \\
\hline NS & NB & NM & NS & NS & ZO & PS & PM \\
\hline ZO & NB & NM & NS & ZO & PS & PM & PB \\
\hline PS & NM & NS & ZO & PS & PS & PM & PB \\
\hline PM & NS & ZO & PS & PM & PM & PB & PB \\
\hline PB & ZO & PS & PM & PB & PB & PB & PB \\
\hline
\end{tabular}

\section{5. 시스템 성능결과}

MPPT 제어는 PSIM을 사용하였으며 각각의 MPPT 회로 도로 그림 10 과 같이 구성하였다.

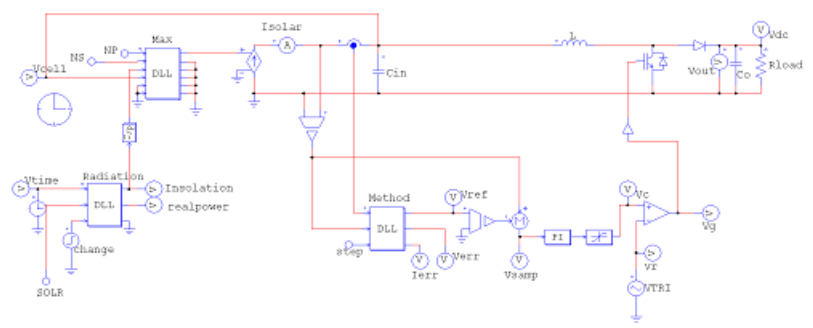

그림 $10 \mathrm{MPPT}$ 제어를 위한 PSIM 회로도

Fig. 10 PSIM circuit for MPPT control

\section{1 일사량이 일정한 경우의 성능 시험}

태양광 발전은 일사량과 온도에 가장 큰 영향을 받는다. 따라서 본 논문에서는 변동하는 경우와 비교하기 전에 일사 량을 임의로 가장 이상적인 상태인 $1000\left[\mathrm{~W} / \mathrm{m}^{2}\right]$, 온도는 45 $\left[{ }^{\circ} \mathrm{C}\right]$ 로 일정하게 하여 성능시험을 하였다.

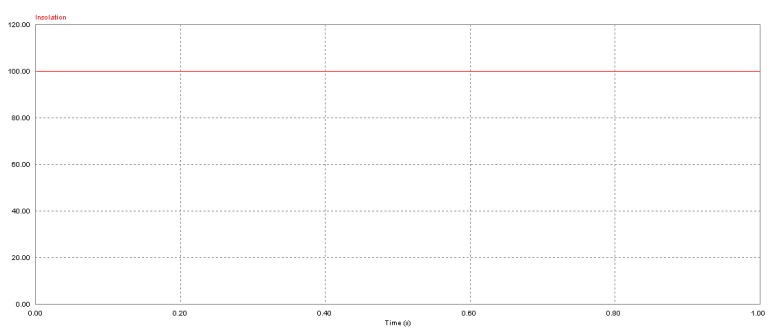

그림 11 태양전지 모듈에 입사되는 일사량

Fig. 11 Radiation of exposed to PV module

\subsubsection{CV 방법}

그림 12 는 $\mathrm{CV}$ 제어방법을 적용하였을 경우이며, 그림 $12(\mathrm{a})$ 는 태양전지의 전압, 그림 $12(\mathrm{~b})$ 는 태양전지의 전류, 그 림 12(c)는 태양전지의 전력을 나타낸다.

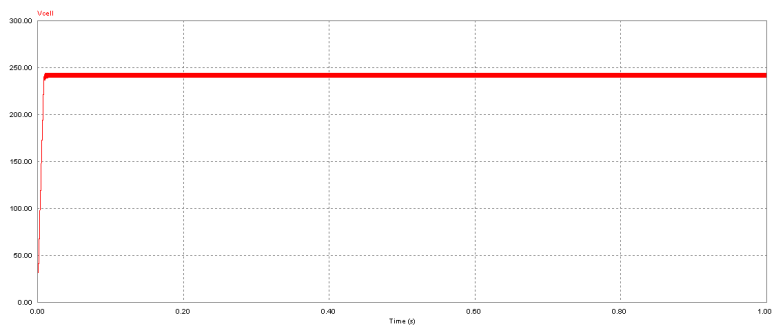

(a) Output voltage of solar cell

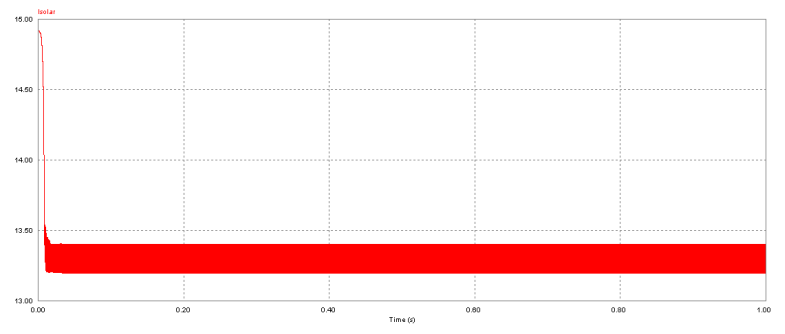

(b) Output current of solar cell

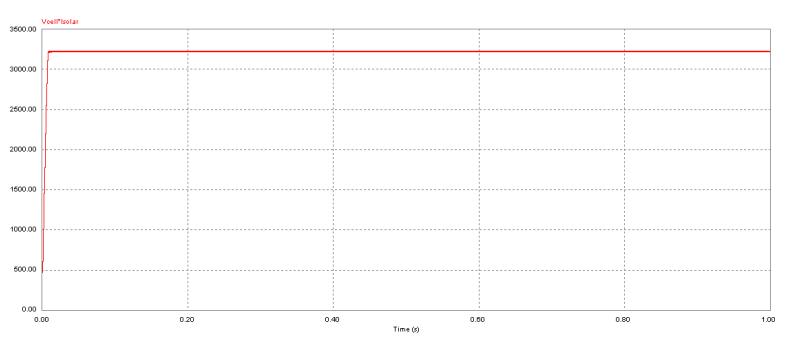

(c) Output power of solar cell

그림 $12 \mathrm{CV}$ 방법에 의한 응답 결과

Fig. 12 The response results of CV method

\section{1 .2 IC 방법}

그림 13은 IC 제어방법을 적용하였을 경우이며, 그림 13(a)은 태양전지의 전압, 그림 13(b)은 태양전지의 전류, 그 림 13(c)은 태양전지의 전력을 나타낸다. 


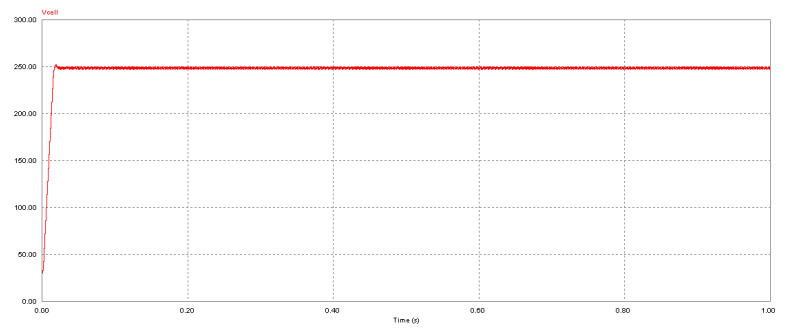

(a) Output voltage of solar cell

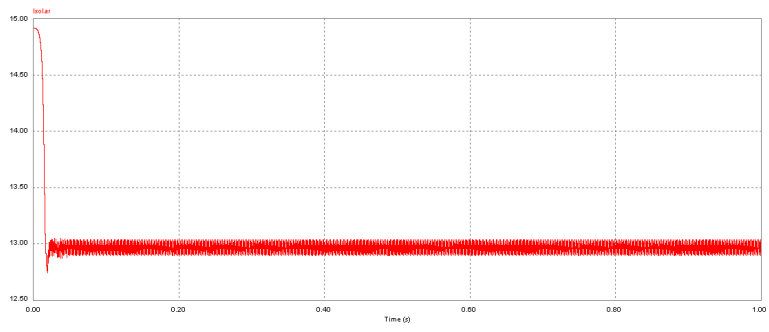

(b) Output current of solar cell

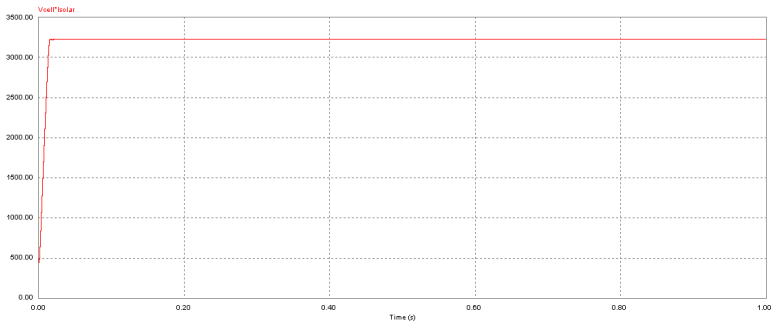

(c) Output power of solar cell

그림 $13 \mathrm{IC}$ 방법에 의한 응답 결과

Fig. 13 The response results of IC method

\subsubsection{PO 방법}

그림 14 는 $\mathrm{PO}$ 제어방법을 적용하였을 경우이며, 그림 $14(\mathrm{a})$ 는 태양전지의 전압, 그림 14(b)는 태양전지의 전류, 그 림 14(c)는 태양전지의 전력을 나타낸다.

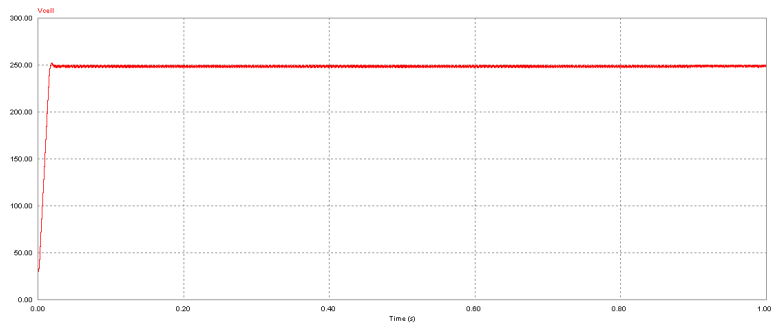

(a) Output voltage of solar cell

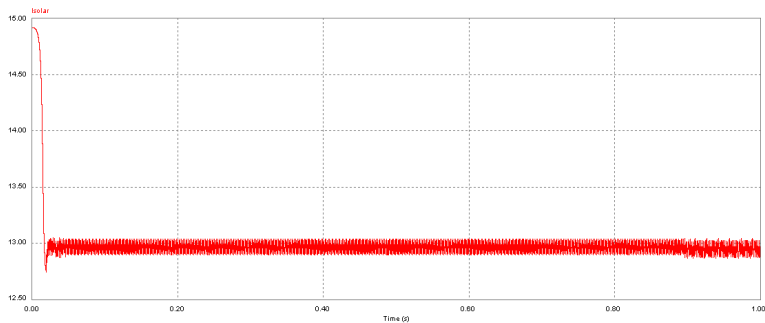

(b) Output current of solar cell

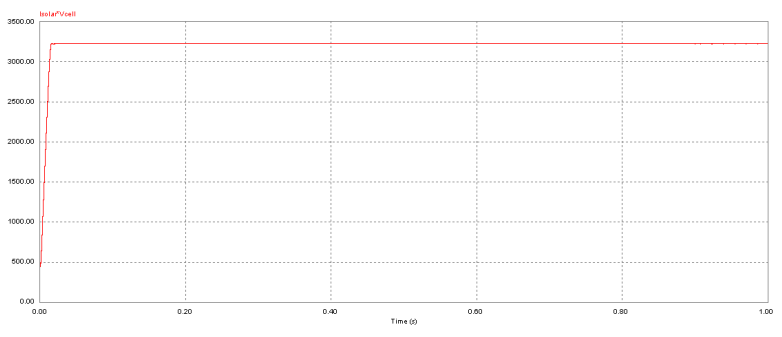

(c) Output power of solar cell

그림 $14 \mathrm{PO}$ 방법에 의한 응답 결과

Fig. 14 The response results of PO method

\subsubsection{NFC 방법}

그림 15는 제시한 $\mathrm{NFC}$ 제어방법을 적용하였을 경우, 그 림 15(a)는 태양전지의 전압, 그림 15(b)는 태양전지의 전류, 그림 15(c)는 태양전지의 전력을 나타낸다.

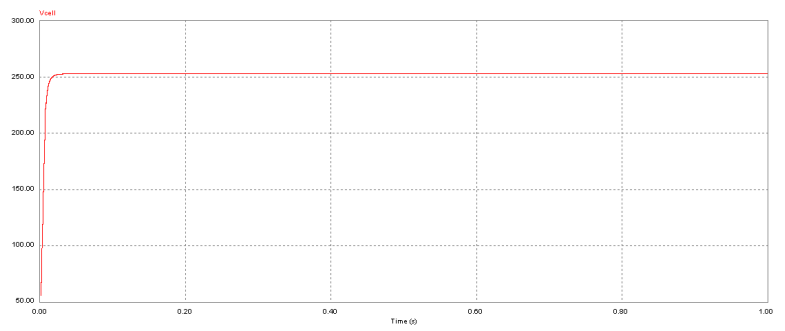

(a) Output voltage of solar cell

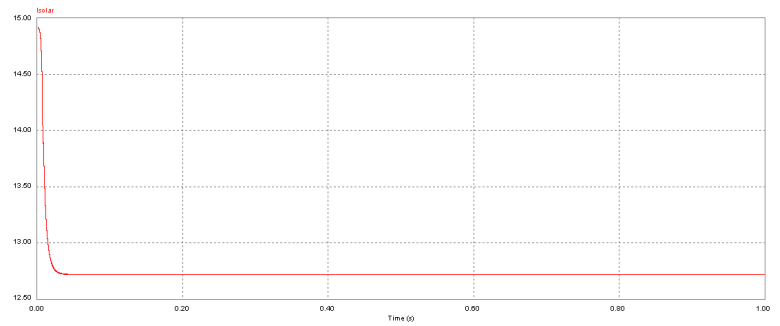

(b) Output current of solar cell

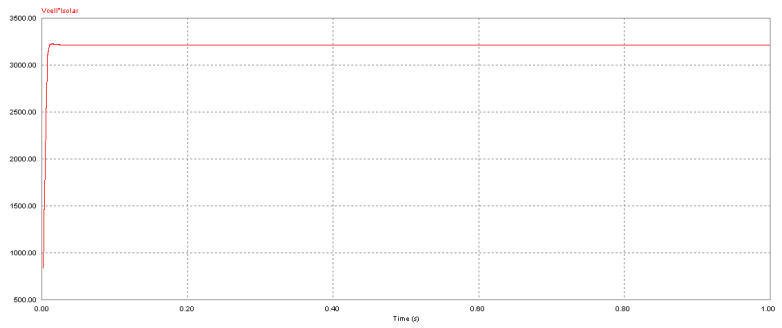

(c) Output power of solar cell

그림 $15 \mathrm{NFC}$ 방법에 의한 응답 결과

Fig. 15 The response results of NFC method

\section{1 .5 일사량이 일정한 경우에 대한 응답 결과 비교}

그림 16 은 MPPT 방법에 따른 태양전지의 전력를 비교하 
기 위해 확대한 그림으로 그림 $16(\mathrm{a})$ 은 $\mathrm{CV}$ 제어방법, 그림 16(b)은 PO 제어방법, 그림 16(c)은 $\mathrm{NFC}$ 제어방법의 응답 특성이며 $0.04[\mathrm{sec}]$ 에서 $0.07[\mathrm{sec}]$ 까지의 정상상태에서 진동 하는 진동 폭을 나타내고 있다. 그림 $16(\mathrm{a})$ 의 $\mathrm{CV}$ 는 peak to peak가 3215[W]에서 3224[W]까지 9[W]만큼 진동하며 그림 16 (b)의 PO 제어방법은 3222[W]에서 3224[W]까지 2[W]만 큼 진동한다. 그림 $16(\mathrm{c})$ 의 $\mathrm{NFC}$ 는 $3224.16[\mathrm{~W}]$ 에서 3224.90[W] 0.74[W]만큼 진동한다. 전압과 전류의 진동 폭 이 가장 작게 나타난 $\mathrm{NFC}$ 제어가 최대 전력점에서의 진동 이 적어 전력소모가 적게 나타남을 알 수 있다.

일사량이 일정한 경우, 컨버터에 의한 MPPT 제어의 태 양전지의 전류, 전압 및 전력을 비교한 결과 정상상태에서 $\mathrm{CV}$ 제어방법의 변동 폭이 가장 크며, $\mathrm{NFC}$ 제어방법의 변 동 폭이 가장 적고 안정적으로 정상상태에 도달하였음을 알 수 있다.

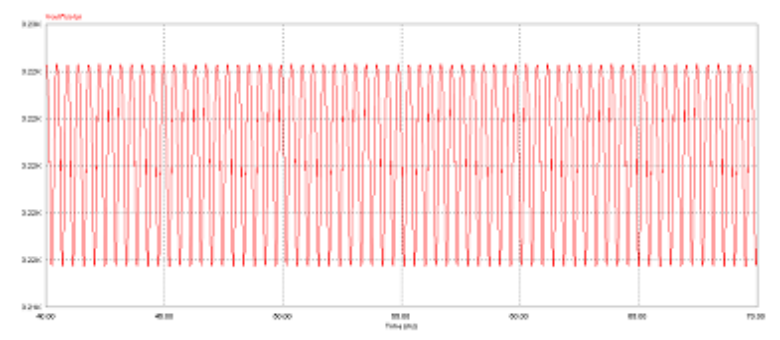

(a) CV control method

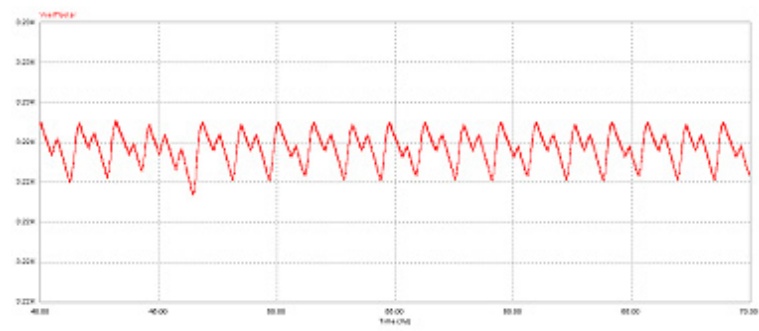

(b) PO control method

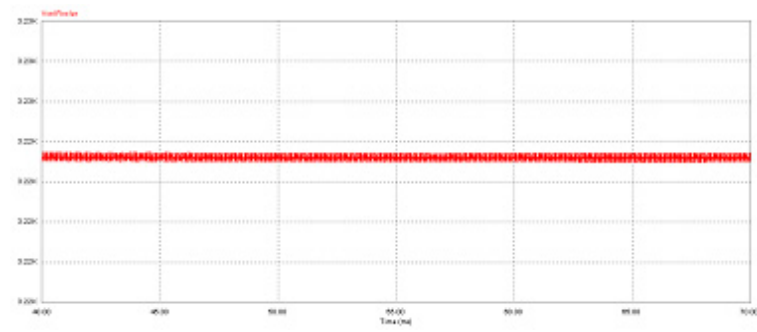

(c) NFC control method

그림 $16 \mathrm{MPPT}$ 제어방법에 따른 전력 응답특성 확대

Fig. 16 Power response characteristics enlargement with MPPT control method.

\section{2 일사량이 변동하는 경우의 성능 시험}

일사량이 변동하는 경우의 성능 시험을 하기 위해 일사량 값을 임의로 $0[\mathrm{sec}]$ 에서 $1000\left[\mathrm{~W} / \mathrm{m}^{2}\right], 0.4[\mathrm{sec}]$ 에서 $600[\mathrm{~W} /$ $\left.\mathrm{m}^{2}\right], \quad 0.6[\mathrm{sec}]$ 에서 $800\left[\mathrm{~W} / \mathrm{m}^{2}\right], \quad 0.8[\mathrm{sec}]$ 에서 $1000\left[\mathrm{~W} / \mathrm{m}^{2}\right]$ 으로 변화시켰다으며 그림 17 에 나타내었다.

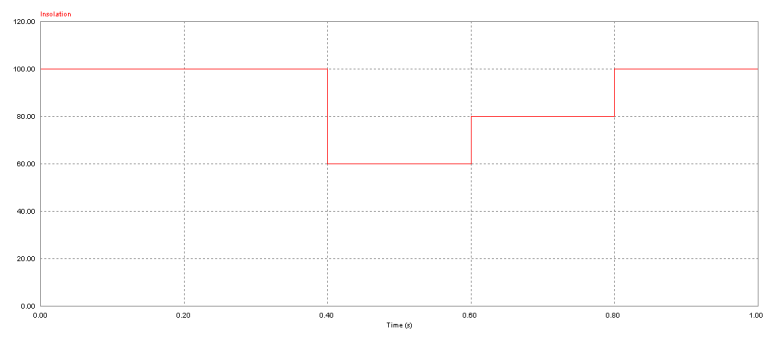

그림 17 태양전지 모듈에 입사되는 일사량

Fig. 17 Radiation of exposed to PV module

\subsubsection{CV 방법}

그림 18은 $\mathrm{CV}$ 제어방법을 적용하였을 경우, 그림 $18(\mathrm{a})$ 은 태양전지의 전압, 그림 $18(\mathrm{~b})$ 은 태양전지의 전류, 그림 18(c) 은 태양전지의 전력을 나타낸다.

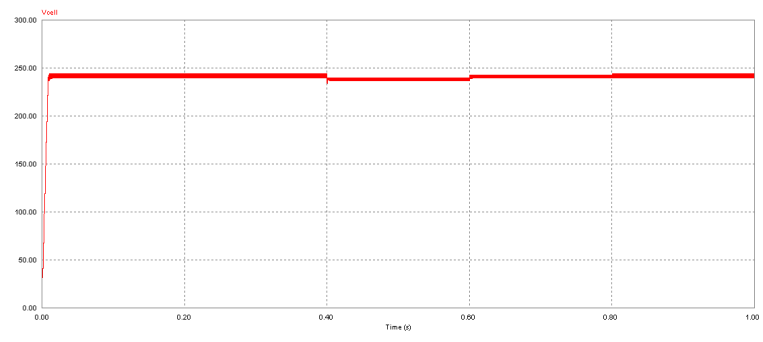

(a) Output voltage of solar cell

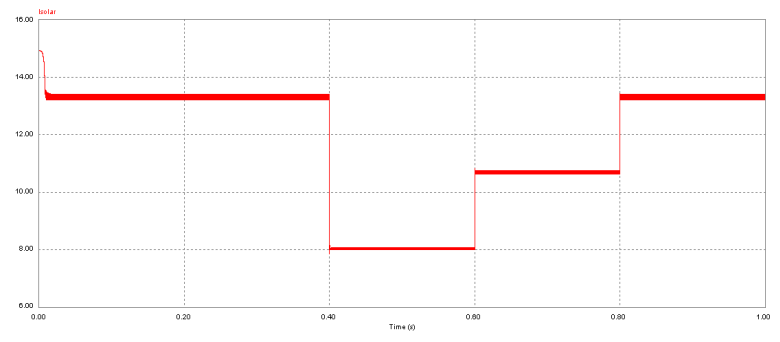

(b) Output current of solar cell

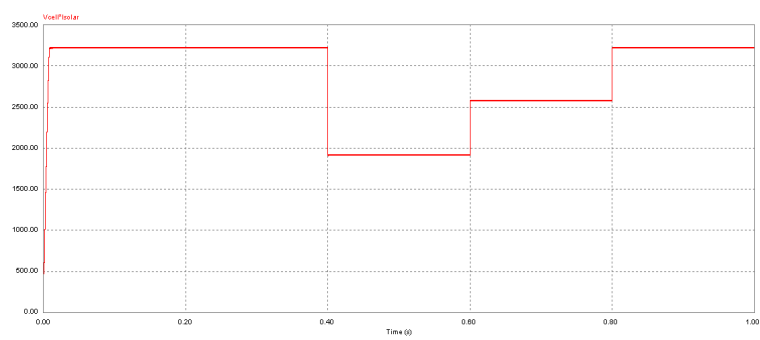

(c) Output power of solar cell

그림 $18 \mathrm{CV}$ 방법에 의한 응답 결과

Fig. 18 The response results of $\mathrm{CV}$ method 


\section{2 .2 IC 방법}

그림 19 는 IC 제어방법을 적용하였을 경우이며, 그림 19(a)는 태양전지의 전압, 그림 19(b)는 태양전지의 전류, 그 림 19(c)는 태양전지의 전력을 나타낸다.

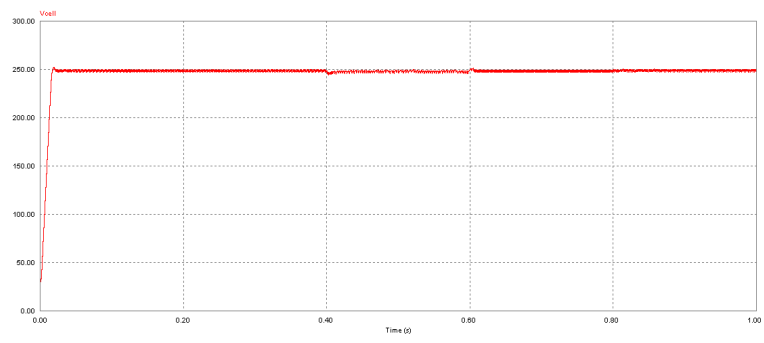

(a) Output voltage of solar cell

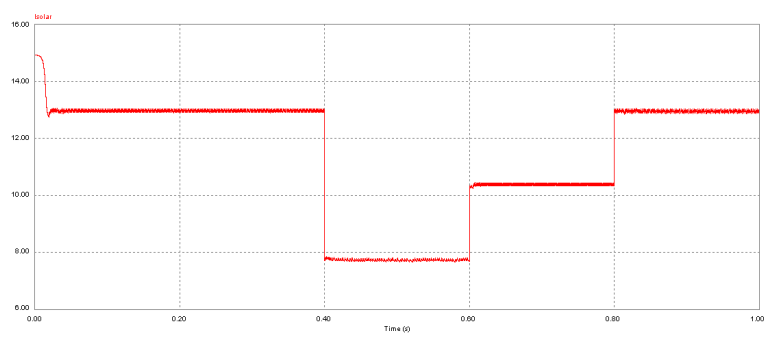

(b) Output current of solar cell

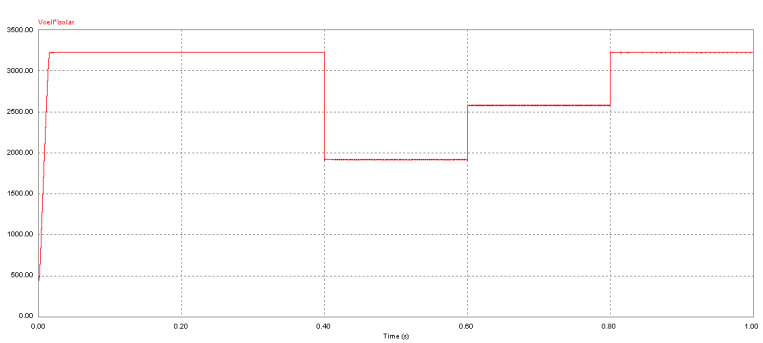

(c) Output power of solar cell

그림 19 IC 방법에 의한 응답 결과

Fig. 19 The response results of IC method

\subsubsection{PO 방법}

그림 20은 $\mathrm{PO}$ 제어방법을 적용하였을 경우이며, 그림 20(a)은 태양전지의 전압, 그림 20(b)은 태양전지의 전류, 그 림 20(c)은 태양전지의 전력을 나타낸다.

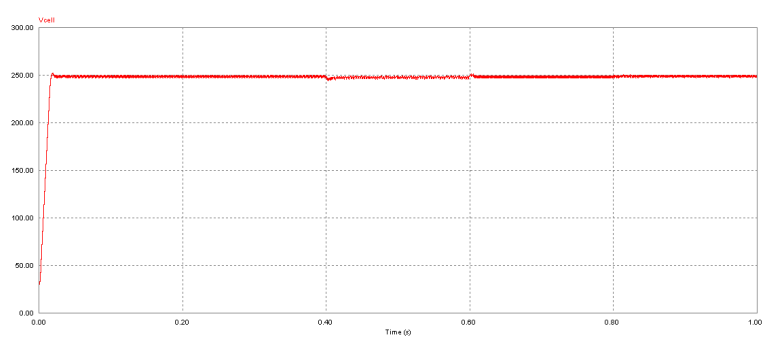

(a) Output voltage of solar cell

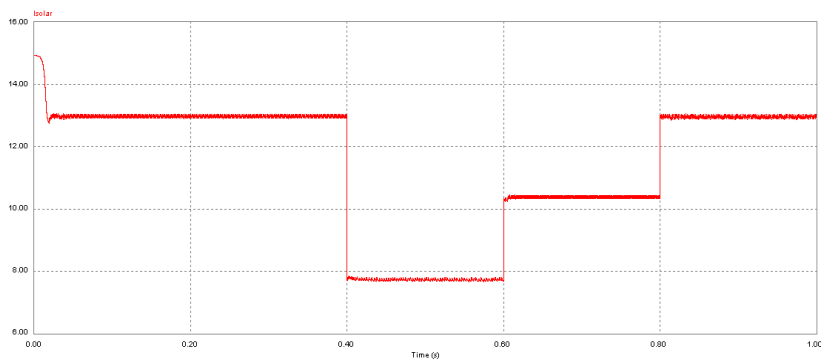

(b) Output current of solar cell

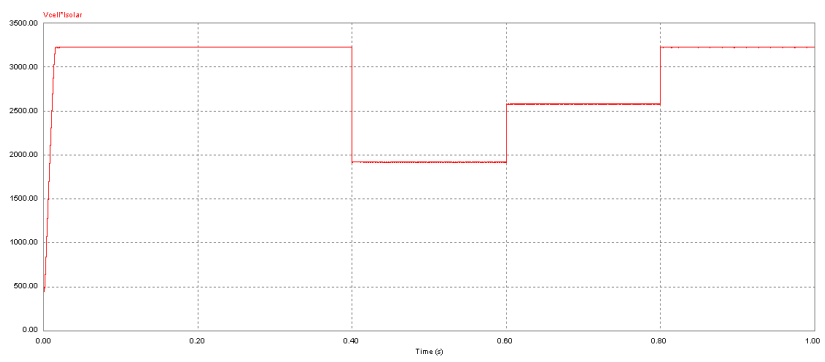

(c) Output power of solar cell

그림 $20 \mathrm{PO}$ 방법에 의한 응답 결과

Fig. 20 The response results of PO method

\subsubsection{NFC 방법}

그림 21은 $\mathrm{NFC}$ 제어방법을 적용하였을 경우이며, 그림 21(a)은 태양전지의 전압, 그림 21(b)은 태양전지의 전류, 그 림 21(c)은 태양전지의 전력을 나타낸다.

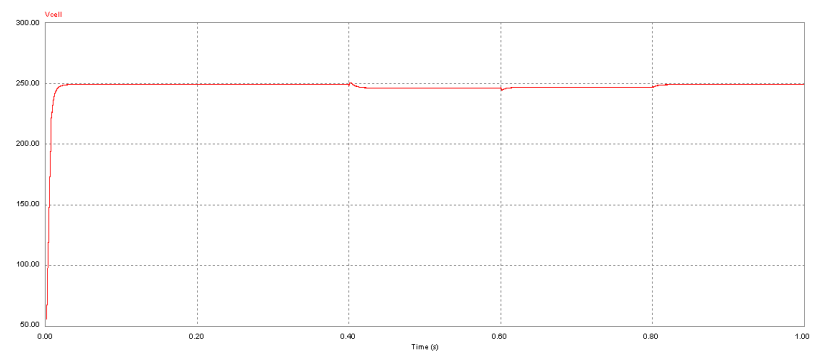

(a) Output voltage of solar cell

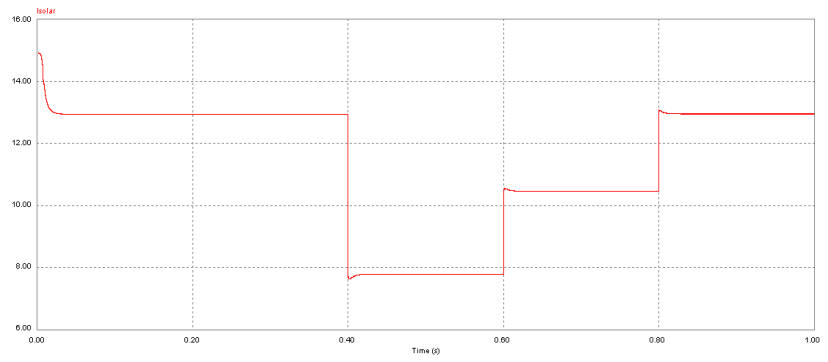

(b) Output current of solar cell 


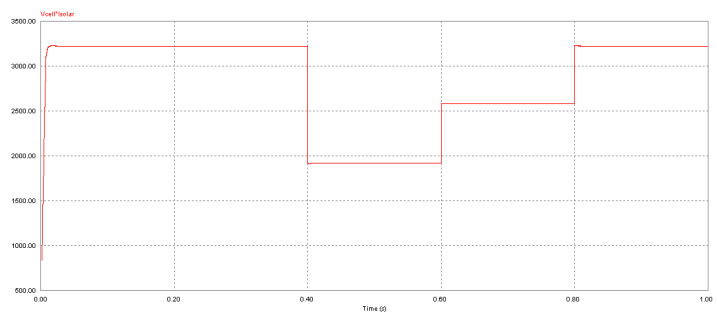

(c) Output power of solar cell

그림 $21 \mathrm{NFC}$ 방법에 의한 응답 결과

Fig. 21 The response results of NFC method

\section{2 .5 일사량 변동에 대한 응답 결과 비교}

일사량이 변동하는 경우 $\mathrm{CV}, \mathrm{IC}, \mathrm{PO}$ 및 $\mathrm{NFC}$ 제어방법의 전력 응답특성을 비교하기 위하여 최대 전력오차를 나타낸다.

그림 22는 기준전력으로부터 MPPT 방법에 따른 0.075[sec]에서 $0.1[\mathrm{sec}$ 까지 태양전지의 최대 전력오차를 확 대한 그림으로 그림 $22(\mathrm{a})$ 는 $\mathrm{CV}$ 제어방법, 그림 22(b)는 $\mathrm{PO}$ 제어방법, 그림 22(c)는 $\mathrm{NFC}$ 제어방법의 오차이다.

그림 $22(\mathrm{a})$ 의 $\mathrm{CV}$ 제어방법에서는 peak to peak가 $-0.258[\mathrm{~W}]$ 에서 $8.224[\mathrm{~W}]$ 까지 $8.482[\mathrm{~W}]$ 만큼 진동하며 그림 22 (b)의 $\mathrm{PO}$ 제어방법은 $-0.829[\mathrm{~W}]$ 에서 $1.865[\mathrm{~W}]$ 까지 $2.694[\mathrm{~W}]$ 만큼 진동한다. 그림 $22(\mathrm{c})$ 의 $\mathrm{NFC}$ 는 $-0.187[\mathrm{~W}]$ 에서 0.259 [W] $0.446[\mathrm{~W}]$ 만큼 진동한다.

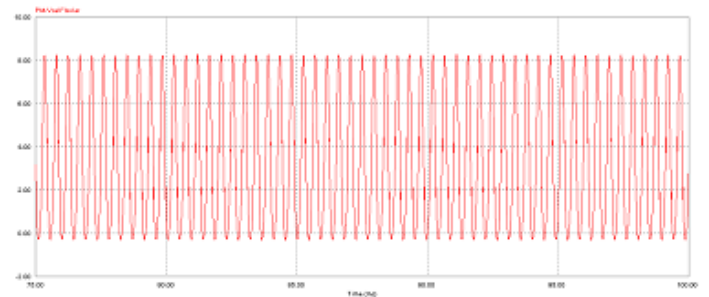

(a) CV control method

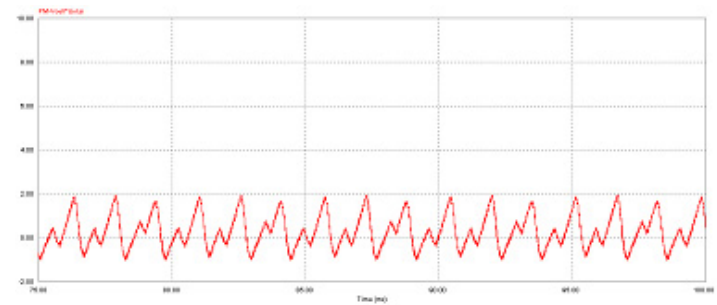

(b) PO control method

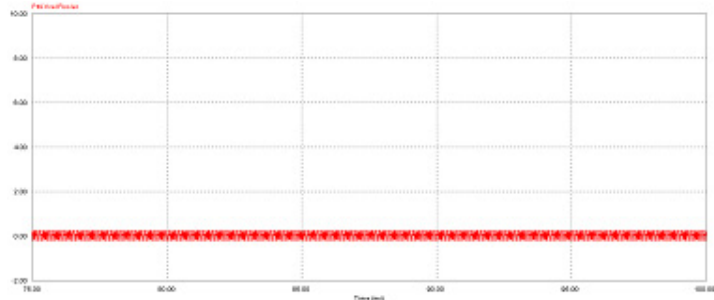

(c) NFC control method

그림 $22 \mathrm{MPPT}$ 제어방법에 따른 최대 전력오차 확대

Fig. 22 Maximum power error enlargement with MPPT control method
일사량이 변동하는 경우, 컨버터에 의한 MPPT 제어의 최대 전력오차를 비교한 결과, $\mathrm{CV}$ 제어방법의 오차가 가장 크고 본 논문에서 제시한 $\mathrm{NFC}$ 의 오차가 가장 적게 나타난 다. 일사량이 일정한 경우와 변동한 경우에도 제시한 $\mathrm{NFC}$ 제어방법이 최대 전력점에 대한 양호한 추종 성능을 확인할 수 있었다.

\section{6. 결 론}

본 논문에서는 일사량 변동에 강인성을 위해 $\mathrm{NFC}$ 제어 기를 이용한 태양광 발전의 새로운 MPPT 제어 알고리즘을 제시하였다. 태양전지의 최대 전력점은 일사량과 온도에 따 라 변하기 때문에 출력 효율을 증가시키기 위해 반드시 $\mathrm{MPPT}$ 제어를 수행하여야 한다. 종래의 MPPT 제어는 $\mathrm{CV}$, $\mathrm{PO}$ 및 $\mathrm{IC}$ 제어방법들이 다양하게 연구되었다. 그러나 종래 의 제어 알고리즘은 환경변화에 대해 MPPT 추종 실패 등 의 문제점이 나타났다.

본 논문에서는 환경변화에 강인한 퍼지제어 기반의 $\mathrm{NFC}$ 제어기를 제시하였으며. 오차는 전력의 변화량에 대한 전압 의 변화량을 사용하였고, 이로써 전류기준 MPPT 제어를 수 행하였다. 또한 제시한 $\mathrm{NFC}$ 제어기는 종래의 퍼지 제어와 차별화하여 오차 및 오차변화분에 대한 정규화 과정을 거치 지 않아 시스템 변수에 대한 강인성을 증가하였다.

제시한 $\mathrm{NFC}$ 제어기는 종래의 $\mathrm{CV}, \mathrm{PO}$ 및 $\mathrm{IC}$ 제어 알고 리즘과 일사량이 일정한 경우와 일사량이 변동할 경우에 대 한 정상상태 응답특성을 비교하였다. 제시한 $\mathrm{NFC}$ 제어기는 종래의 알고리즘에 비해 일사량이 일정 및 변동에 대해 정 상상태의 자려진동이 적게 나타나 출력 손실을 줄일 수 있 었다. 이로써 본 논문에서 제시한 $\mathrm{NFC}$ 제어 알고리즘의 타 당성을 입증할 수 있었다.

\section{참 고 문 헌}

[1] 송길영, “최신 발전공학”, 동일출판사 pp. 1 30

[2] 한전기술연구원, "소규모 계통선 연결형 태양광발전 시 스템 개발",

KRC-89G-J08, pp. 149-151, 1992

[3] 송진수, “태양광발전 기술의 개발동향 및 국내현황”, 대 한전기학회 하계학술대회 논문집, pp. 859-862, 1994

[4] 김슬기, 전진홍, 김응상 "PSCAD/EMTDC를 이용한 계 통연계형 태양광발전시스템의 모델링 및 모의 해석”, 대한전기학회 논문지, 제 $54 \mathrm{~A}$ 권, 제 3 호, pp. 107-116, 2005.

[5] 한전 배전처, "분산형 전원 배전계통 연계 기술 해설 서”, 한국전력공사, 2006.

[6] A Brambilla, "New Approach to Photovoltaic Arras Maximum Power Point Tracking", Proceeding of 3_th IEEE Power Electronics Conference, Vol. 2, pp. 632-637, 1998

[7] Brad Bryant, Marian K.Kazimierczuk, "Modeling the Closed- Current Loop of PWM Boost DC/DC Converters Operating in CCM with Peak Current-Mode Control.", IEEE Transactions on 
Circuits and Systems-Regular Papers, Vol. 52, No. 11, pp. 2404-2412, 2005.

[6] 이상용, "외란에 강인한 최대 전력점 추종기를 갖는 태 양광 발전 시스템에 관한 연구”, 건국대학교 대학원, 석 사학위 청구논문, 2003.

[7] 강안중, 김태우, 김학성, “ 일사량 급변에 대한 $\mathrm{P \& O}$ 알 고리즘 개선”, 전력전자학회 전력전자학술대회 논문집, pp. 117-120, 2004.

[8] 설재웅, 장재정, 김동민, 이승혁, 김진오, “증분컨덕턴스 $\mathrm{MPPT}$ 제어 기반 계통연계형 태양광 발전시스템의 전 력품질 평가”, 대한전기학회 논문지, 제 56 권, 제 1 호, pp. 8-13, 2007

[9] N. Femia, G. Petron, G. Spagnuolo, and M. Vitelli, "Optimization of perturb and observe maximum power point tracking method," IEEE Trans. Power Electron., Vol. 20, no. 4, pp. 963-973, 2005.

[10] P. Wolfs, Q. Li "A current-sensor-free incremental conductance single cell MPPT for high performance vehicle solar arrays" PESC06. pp. 1-7, 2006.

[11] L. Zhanlg, A. Al-Amoudi, Y. Bai, "Real-time maximum power point tracking for grid-connected photovoltaic systems", IEEE Pabl. No. 475, pp. 124-129, 2000.

[12] Tae-Kyung Kang, Kang-Hoon Koh, Young-Cheal Kim, "The study on MPPT algorithm for improved incCond algorithm" 한국태양 에너지학회. pp. 299-306, 2004.

[13] E. Roman, P. Ibanez, S. Elorduizapatarietxe , R. Alonso, D.Goitia, and I. Martinez de Alegia "Intelligent PV module for grid-connected PV systems," in Proc. IEEE 30th Annual Conference of the IEEE Industrial Electronics Society, pp. 3082-3087, 2004.

[14] X. Sun, W. Wu, X. Li, Q Zhao, "A research on photovoltaic energy controlling system with maximum power point tracking", Proc. of PCC '02, Vol. 2, pp. 822-826, 2002.
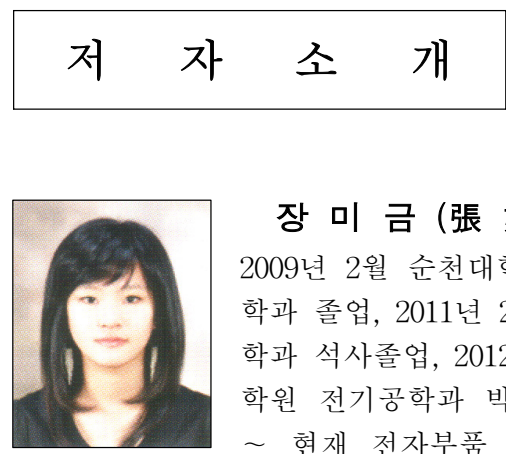

\section{장 미 금 (張 媚 琴)}

2009년 2월 순천대학교 공대 전기제어공 학과 졸업, 2011년 2월 동 대학원 전기공 학과 석사졸업, 2012년 3월 현재 동 대 학원 전기공학과 박사과정, 2011년 12월 현재 전자부품 연구원 디지털컨버전 스연구센터 연구원

Tel : (062)975-7037

Fax : (062)975-7039

E-mail : kumi0145@keti.re.kr

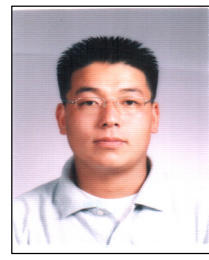

\section{최 정 식 (崔 正 植)}

1980년 2월 9일생, 2005년 순천대학교 공 대 전기제어공학과 졸업, 2007년 2월 동 대학원 전기공학과 졸업(석사), 2011년 2 월 동 대학원 전기공학과 졸업(박사), 2011년 1월 현재 전자부품연구원 선 임연구원.

Tel : (062)975-7038

Fax : (062)975-7039

E-mail : cjs1108@keti.re.kr

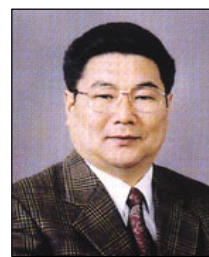

\section{정 동 화 (鄭 東 和)}

1979년 영남대 공대 전기공학과 졸업. 1981년 한양대 대학원 전기공학과 졸업 (석사). 1987년 동 대학원 전기공학과 졸 업(박사). 1988년 1989년 현 대중전기(주) 기술연구소 책임연구원.1989년 현재 순천 대학교 정보통신공학부 교수

Tel : 061-750-3543,

Fax : 061-752-9841

E-mail : hwa777@scnu.ac.kr 